\title{
EXTREME PHYSICAL EVENTS IN THE SUB-ANTARCTIC
}

\author{
by Patrick G. Quilty
}

\author{
(with seven text- igures and two plates)
}

\begin{abstract}
Quilty, P.G. 2012 (14:xii): Extreme events in the sub-Antarctic. Papers and Proceedings of the Royal Society of Tasmania 146: 63-69. https://doi.org/10.26749/rstpp.146.63
\end{abstract}

ISSN 0080-4703. School of Earth Sciences, and Institute of Marine and Antarctic Studies (IMAS), University of Tasmania, Private Bag 79, Hobart, Tasmania 7001, Australia. Email: P.Quilty@utas.edu.au

Extreme physical events, excluding meteorological events, can be divided into two broad categories — endogenous and exogenous. Endogenous phenomena include earthquakes, landslides, tsunami, volcanic or gas hydrate eruptions that occur within the region but may have both local and distant impacts; the 2011 Puyehue-Cordon Caulle volcanic eruption, and the frequent major earthquakes along the Chile margin or near Macquarie Island are examples. Exogenous events are those originating outside the area but influencing it. These include the terminal Cretaceous asteroid impact, asteroid/meteorite impacts, such as the major Eltanin Asteroid impact 2.5 million years ago, and extraterrestrial-sourced radiation from extreme solar/galactic or extra-galactic events in which the effect is not confined to the sub-Antarctic but is global.

Key Words: sub-Antarctic, volcanic eruptions, earthquakes, landslides, gas hydrates, asteroid/meteorite impacts, space weather.

\section{INTRODUCTION}

The sub-Antarctic is now recognised as a separate realm (Green 2007), differing from the glacial realm to its south and the temperate realm to its north. It is a uniquely Southern Hemisphere feature covering some $8 \%$ of the Earth's surface and linking the southern extremities of the three great oceans - Indian, Pacific and Atlantic (fig. 1). This paper discusses the concept of extreme events in the realm, events that are out of the range of normally expected or experienced occurrences. It concentrates on the non-meteorological extreme events and distinguishes those events that are endogenous (generated within the realm) and exogenous (those that impact from outside the realm). Examples of the former are volcanic eruptions and landslides, and the latter, mainly space-sourced events such as extreme cosmic ray fluxes or meteoritic impacts.

\section{ENDOGENOUS EVENTS AND THEIR CONTROL}

Endogenous events are those generated within the realm itself or internally in the Earth and are easily recognised as such. These include earthquakes, volcanic eruptions, landslides and tsunami. While discussed separately here, there are marked interactions between the events; for example, volcanic eruptions can give rise to earthquakes, landslips and tsunami.

\section{Earthquakes}

There are many mechanisms for the generation of earthquakes and some generalisations can be made. Most are small (> or $=3$ on the Richter Scale) at mid-ocean ridges, mainly on transform faults that cut, and are perpendicular to, the ridge crests (fig. 2). They also are shallow (generally $<30$ $\mathrm{km}$ below the Earth's surface). In marked contrast are those characteristic of subduction zones. In the sub-Antarctic, the most likely regions are the Scotia Arc (fig. 3) where the Atlantic Ocean seafloor is subduced below the Antarctic plate, and the southwestern margin of South America, close to the source of the world's strongest recorded earthquakes.
Here, the Pacific Plate descends to depths of almost 700 $\mathrm{km}$ and generates deep and very high-energy earthquakes. Movement along these zones may be continuous (a few $\mathrm{cm}$ per year when many small earthquakes of little significance may be generated) or intermittent (when movement is halted by friction for long periods, only to be released dramatically when the locked condition is overcome; major disasters in the last few years were of this type). Because there is a large vertical component to the movement, major tsunami are a feature of this type of earthquake.

An unusual site is that on Macquarie Ridge near Macquarie Island where, in an oceanic setting, two plates collide obliquely. The Indian-Australian Plate is moving due north at about $6 \mathrm{~cm}$ per year, and to its east the Pacific Plate is moving slightly west of north. The region regularly experiences large earthquakes that are basically of one slab sliding past another but tsunami are minor. Earthquakes of magnitude 7 occur almost every year.

While transform faults generally produce small earthquakes, there was an exception in March 1998, when, by that time for the year, the largest earthquake on Earth (8.1) occurred at the southern end of one of these features (fig. 4). It was at $62^{\circ} 49.566^{\prime} \mathrm{S} ; 149^{\circ} 40.26^{\prime} \mathrm{E}$, at a depth of $10 \mathrm{~km}$ and was most unexpected in that setting.

\section{Volcanic eruptions}

Most islands in the sub-Antarctic are volcanic in origin and much of that volcanism is basaltic in composition and expression. They are thus expected to be subject to quiet eruptions. An exception is the Scotia Arc or South Sandwich Islands, linking the northeastern end of the Antarctic Peninsula to South America (fig. 3). This is the only region of the Antarctic Plate where subduction is active, leading Atlantic Ocean seafloor dipping steeply westwards at $75^{\circ}$ beneath the small Sandwich Plate. Quilty (2007) provided a summary of activity in the region. It is likely that subduction has been active and continuous for the last $15 \mathrm{Ma}$ (Leat et al. 2007). The volcanoes are typical of those found over such subduction zones elsewhere but have their own characteristics.

In 1962, there was a previously unrecorded event when Protector Shoal (previously unknown with its summit at 


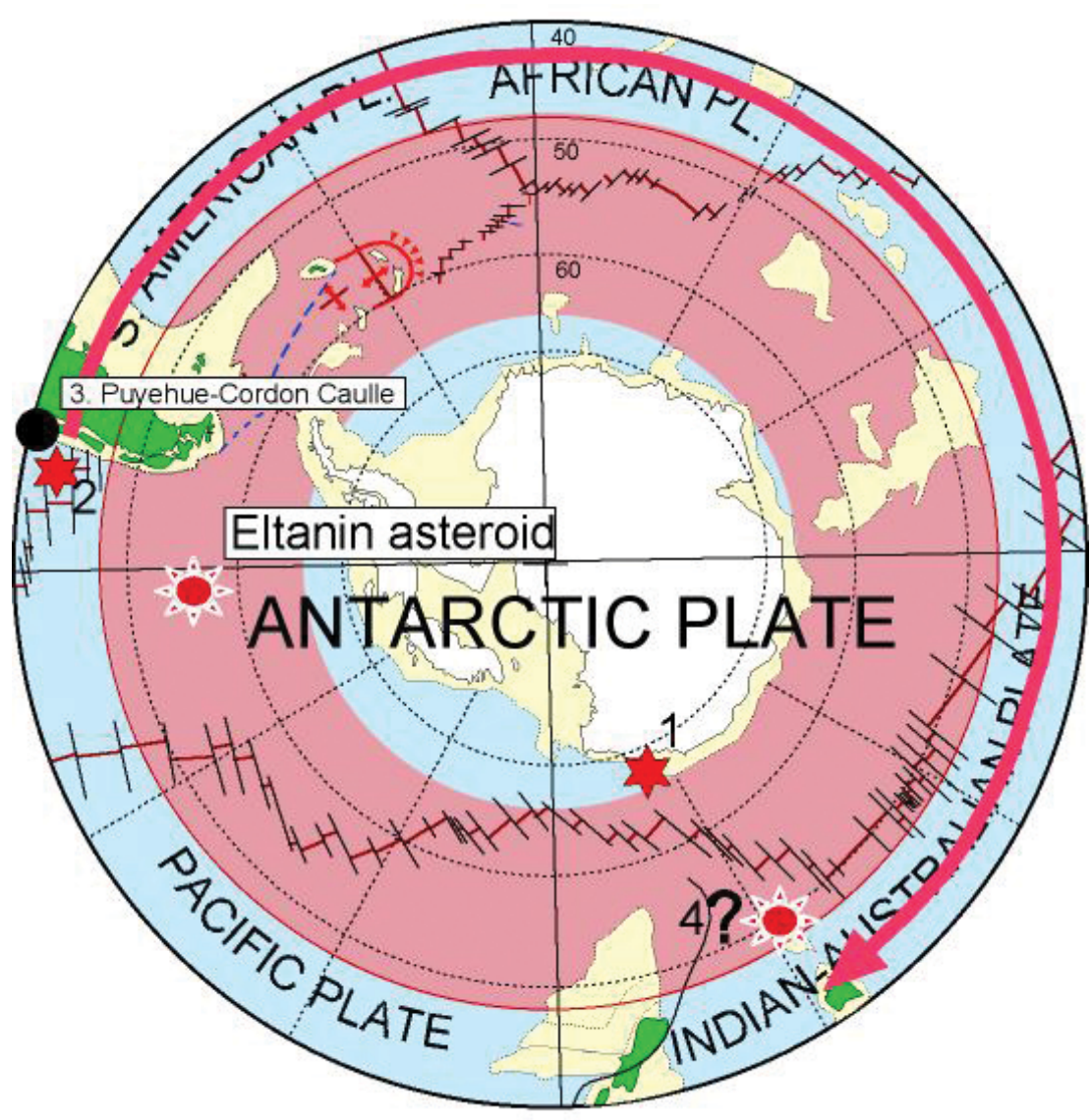

FIG. 1 - Modern Antarctica showing major tectonic features and location of some events mentioned in text. SubAntarctic realm indicated in deep pink. 1. Record of the largest earthquake on Earth known from the first three months of 1998. 2. The site near Chile of the largest earthquake recorded on Earth. 3. Site (black filled circle) of volcano Puyehue-Cordon Caulle that erupted in 2010 causing major disruption to Southern Hemisphere air travel. Travel direction around Southern Hemisphere indicated. 4. Site of possible impact site close to Tasmania. Eltanin asteroid impact site also shown.
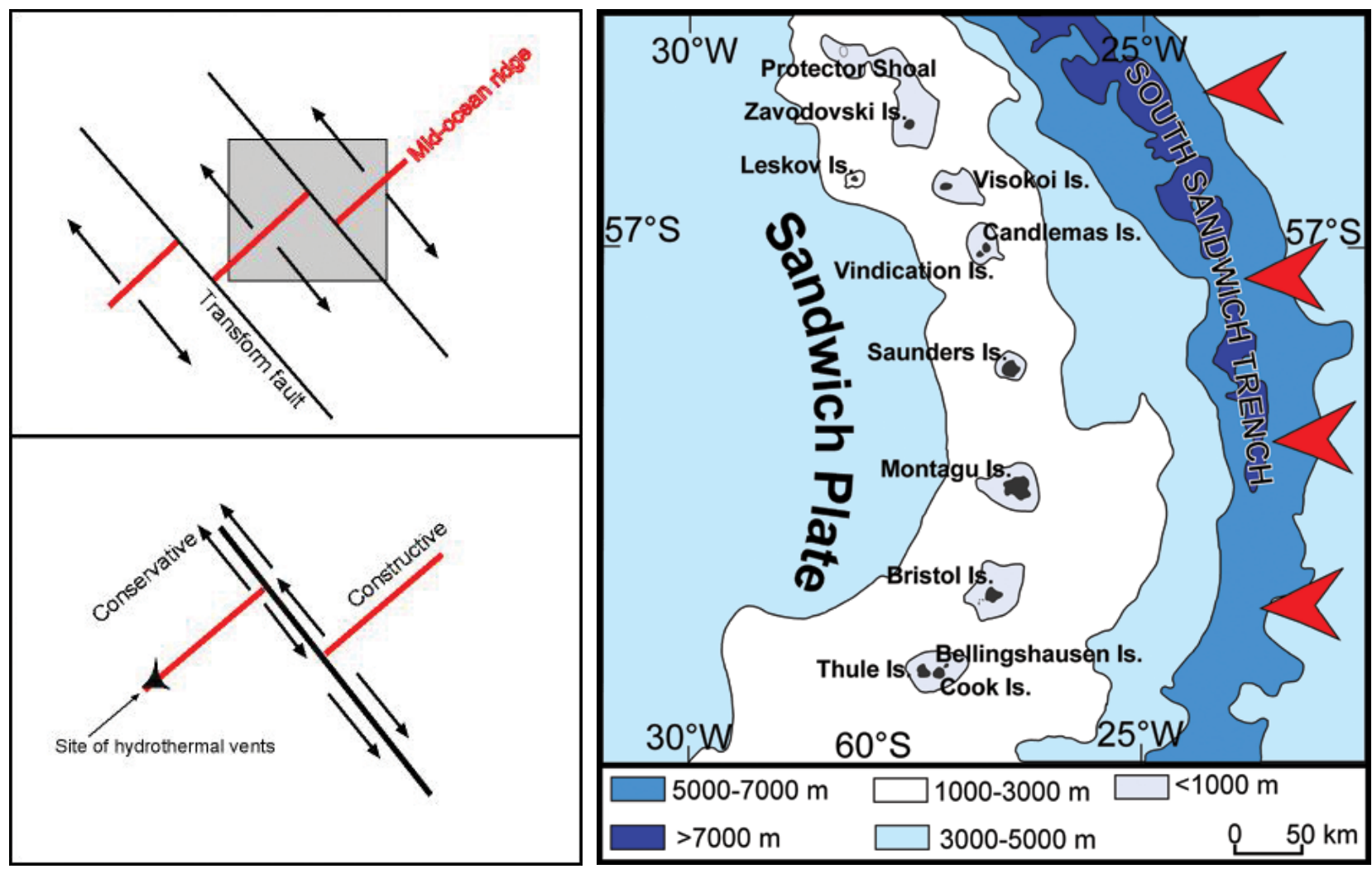

FIG. 2 - Geometry of transform faults.

FIG. 3 - Setting of South Sandwich Islands illustrating subduction of South Atlantic tectonic plate beneath the Antarctic plate. 
$27 \mathrm{~m}$ below sea level) erupted a vast raft of pumice (Gass et al. 1963, Sutherland \& Olsen 1968). That raft circled the Southern Hemisphere for many years, slowly becoming more dispersed, the fragments smaller, and providing glass shards to the seafloor to contribute to the sediment. Some of the floating fragments initially were as large as about one metre in diameter and accumulated particularly on the western side of Southern Hemisphere landmasses.

The eruption perhaps provides another mechanism for transport of vegetation propagules around the region, a means of colonising new islands. Such large fragments may remain on island margins for many years, and because they are so large, may become vegetated. Storm activity may then remove them, and currents carry them normally eastwards until they come aground on a new location where they bring new vegetation and marine species that became established en route.

The recent eruption of Puyehue-Cordon Caulle (pl. 1) is an example of an eruption that, while not very extreme in volcanic eruption terms, is big enough to have had a widespread effect on Southern Hemisphere economies, particularly by disrupting air services. Strictly, it is outside the sub-Antarctic at $40^{\circ} 25^{\prime} \mathrm{S}$, but the plume apparently did flow into the sub-Antarctic regions.

\section{Tsunami}

Many of the events discussed throughout this paper may generate tsunami. Volcanic eruptions, earthquakes and major downslope land movements are recognised from welldocumented experience elsewhere as causing tsunami. There are ample recent examples in the public mind.

\section{"Landslides", gas hydrates and related phenomena}

Landslides: The area available for traditional subaerial landslides in the sub-Antarctic is very small - some 6500 $\mathrm{km}^{2}$ (excluding Îles Kerguelen and some more northerly islands); however, land movements are occurring. Quilty (1989) reviewed the landslide issue for the Antarctic and included comments on the sub-Antarctic. Several factors make this worth re-examining. First, many of the landmasses, while small, are steep-sided and composed of friable debris.
Second, the projected direction of climate change indicates that the region will warm, and the regolith is likely to become more unstable as groundwater availability increases. Plate 2 illustrates the scale and potential impact of landslides on steep slopes, in this case at Lusitania Bay, Macquarie Island.

Island margin collapse: Gough Island has evidence of largescale collapse structures that have left a series of arcuate scars (fig. 5). The island formed over the last million years and the scars suggest that collapse events occur every 200000 years or more often. These events are major earth movements and could be expected to generate significant tsunami, depending on whether or not they were essentially instantaneous or occurred slowly. Bouvet Island shows evidence of collapse to the northwest. St Paul Island has an almost straight northeast margin where part of the island has disappeared but whether this is simple large-scale landslip or tectonically controlled faulting is unclear (fig. 6).

It is already clear that major landslips have occurred on Heard Island (Quilty 2007) where a scar on the southwest flank is the site of a debris avalanche, leaving behind the escarpment in which the small active volcano of Mawson Peak developed (fig. 7). The ocean is shallow to the southwest of the island, marking the site of deposition of the avalanche content. The age and repeat frequency of such events are unknown but many of the sub-Antarctic islands are volcanic in origin with steep sides and this relatively large-scale phenomenon can be expected to recur.

On a much smaller scale is the continuing gentle downslope movement of regolith on the flanks of the islands or steep geomorphic features, and marginal to lakes.

Turbidity currents/debris flows: What is unknown is the scope for major submarine downslope movements adjacent to Antarctica and the islands. It is apparent that all islands and the continent have steep sides that extend into the deep ocean and there are likely to be submarine canyons at approximately the same concentration as in other parts of the world where they have been studied in more detail. Such canyons are active conduits for the slumping of sediment from shallow to deep water and are important in geological history. They are well-known as affecting human installations such as submarine cables (Heezen \& Ewing 1952).

Gas hydrates: Seismic studies around the Antarctic have identified Bottom Simulating Reflectors (BSR), the result of

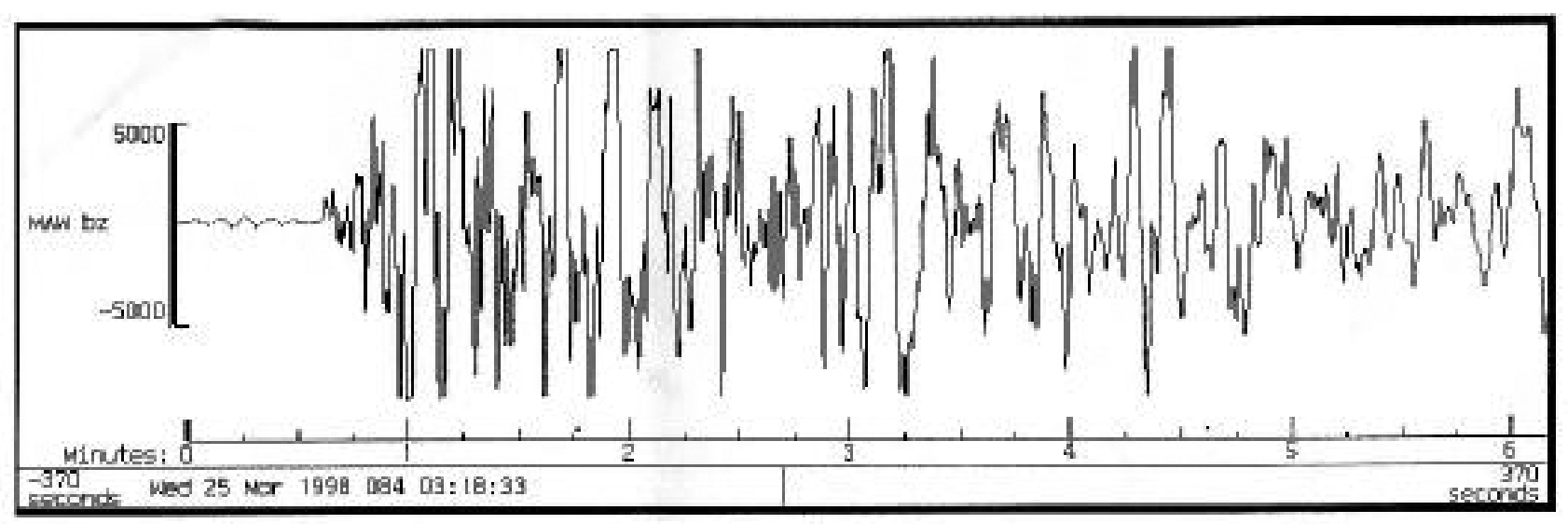

FIG. 4 - Record of the largest earthquake on Earth for the first three months of 1998. Locality indicated on fig. 1. 


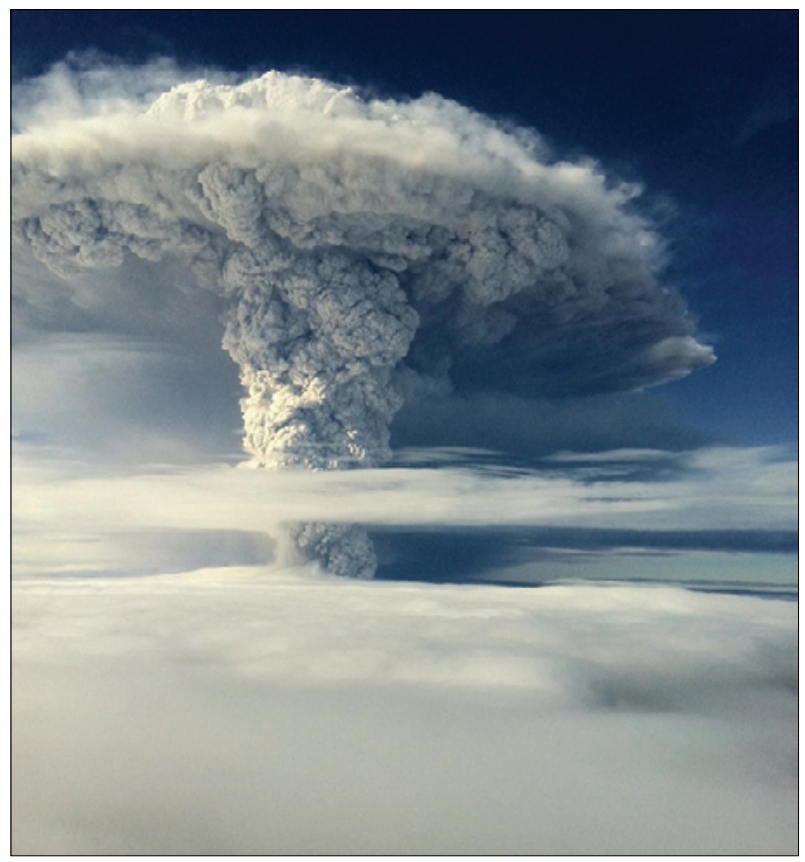

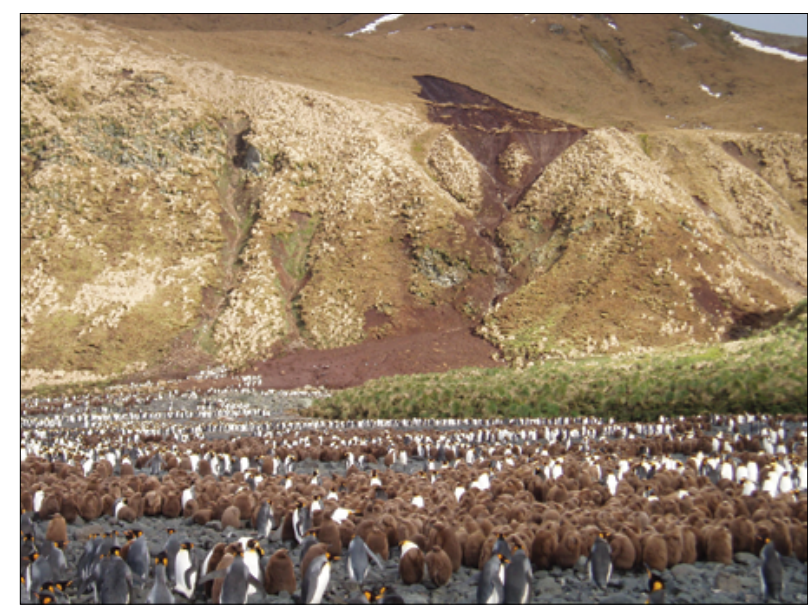

PLATE 2

Landslide at Lusitania Bay, Macquarie Island. Image courtesy of Noel Carmichael.

\section{PLATE 1}

Volcano Puyehue-Cordon in eruption, 2010. Locality indicated on fig. 1. Image courtesy of Larry Lackey.

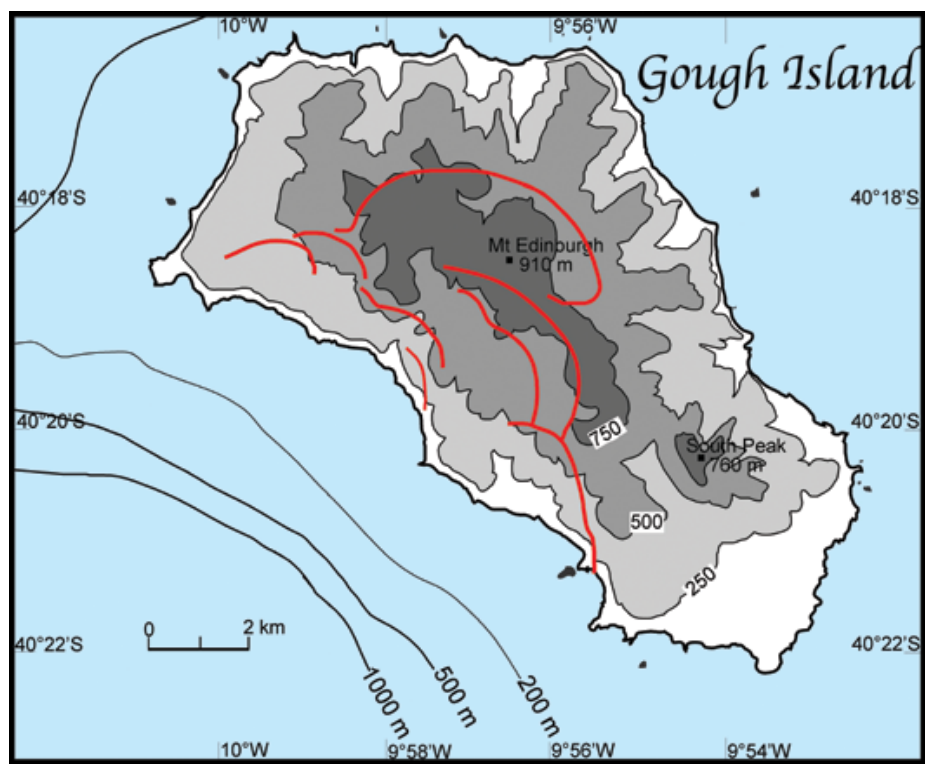

FIG. 5 - Major landslips on Gough Island, South Atlantic Ocean. Periodically, large slabs of the island slide into the Atlantic Ocean, controlling much of the island's topography.

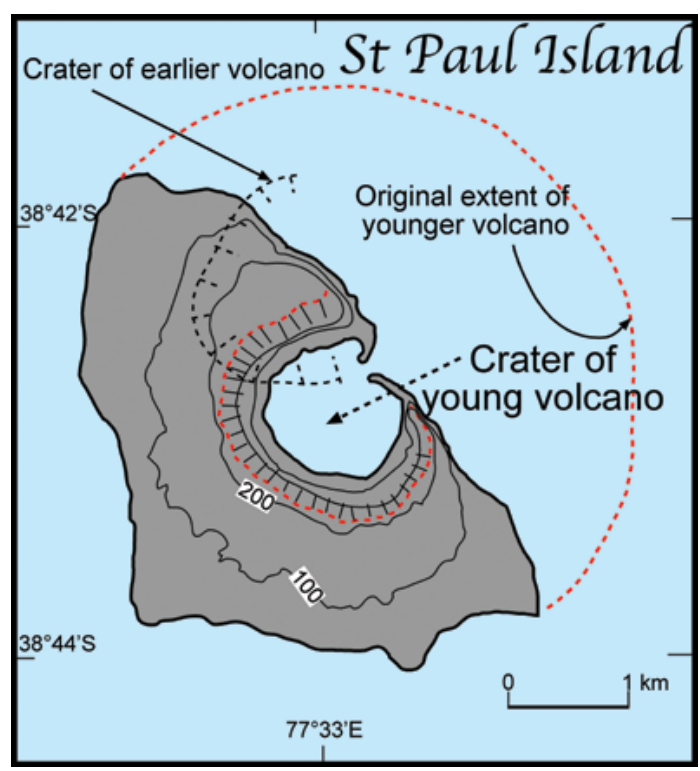

FIG. 6 - St Paul Island, Indian Ocean, showing how northeast margin of the island is controlled by either landslip or fault movement. the existence of gas hydrates or methane hydrates, usually at 300-500 m below the seafloor. Gas hydrates are regarded by some as the major reservoir of methane on Earth. They are only metastable due to low temperature and the pressure of water above. A concern to some in the climate change science community is that changes in oceanic parameters (especially temperature) may overcome the metastability causing the release of the methane. This possibility is taken by many (e.g., Svensen et al. 2004) to be the likely cause of the Paleocene/Eocene Thermal Maximum (PETM) at
55 million years (Paleocene/Eocene boundary) when the largest ${ }^{12} \mathrm{C}$ excursion known led to a great increase in global temperatures and a major extinction event. Of course, such an event would be global but the sub-Antarctic would be included in the effects.

It is thought that some modern continental margin collapses may be due to this feature and thus it is possible that the Antarctic continental margin (especially because it is so deep) could be affected providing significant flows of sediment to the deep ocean floor of the sub-Antarctic. 


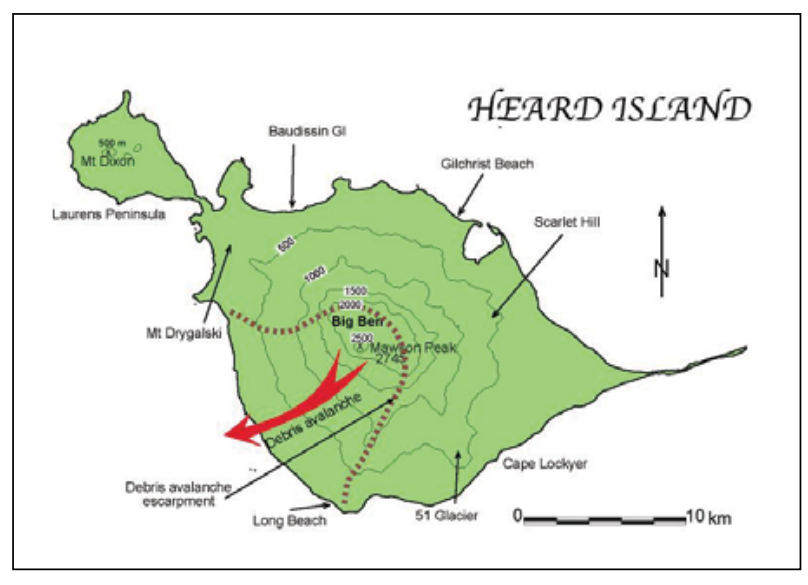

FIG. 7 - Heard Island, south central Indian Ocean, showing site of debris avalanche that removed a large slab of the island and deposited it to the southwest.

\section{Magnetic field reversals/geomagnetic excursions}

It is well known that the Earth's magnetic field reverses from time to time, the most recent at about $750 \mathrm{ka}$. The pattern is now well documented and is used routinely in analysis of cores taken by scientific drilling programs such as the Ocean Drilling Program (ODP). This phenomenon is global in its effects and this makes it valuable as a dating technique.

What is less well known and understood is the phenomenon of geomagnetic excursions, the last one of significance at about $40 \mathrm{ka}$ and recorded in ice cores - the Laschamp event (Guillou et al. 2004). During such an excursion, the field strength can fall to less than $20 \%$ of normal and the orientation of the field can vary for up to about 7000 years, by $45^{\circ}$. This disorientation can be regional and sometimes global. The causes are unclear and there are a few hypotheses. One hypothesis is that the cause lies in the outer core of the Earth which is liquid of very low viscosity, where field lines are thought to become "tangled" (Gubbins 1999). An alternative hypothesis suggests that the cause is tectonic, due to changes in the core/mantle boundary induced by some deep subduction control, by impacts, or by events at mantle plume generation. Some aspects of the latter hypothesis make sense in relation to regionalisation of the result.

\section{EXOGENOUS EVENTS}

Exogenous events are those generated outside the region, or even dominantly, the Earth, and which cannot, as yet, be predicted. Included here particularly are space-related events such as meteorite impacts, solar influences and cosmic ray phenomena. Any effects in the sub-Antarctic are only part of global impact.

\section{Meteorites/asteroid impacts}

Space is a source of some sediment in the region but its contribution is swamped by "normal" sedimentation, and hardly extreme. By contrast, meteorites and related impacts do constitute extreme events and, although observational data for the region are very few due to lack of exploration, there is evidence that impacts have occurred and it is possible to make estimates of the likely rate and size of those impacts

In the mid-1960s, USNS Eltanin recovered Core 13-4 (57\%47.2'S; 9047.6'W; $4700 \mathrm{~m}$ water depth) which incorporated asteroidal debris and led to further detailed examination of the area in the 1990s and currently. Gersonde et al. (1997 et seq.) reported further on the site, following a major expedition to the region, and were the first to analyse evidence for this major asteroid impact in the Southern Ocean - the Eltanin asteroid (fig. 1). This was dated at c.2.5 Ma (late Pliocene or now earliest Pleistocene) and estimated to have had a diameter of $1-4 \mathrm{~km}$. Evidence is now known from an area over $1000 \mathrm{~km}$ wide. At $1 \mathrm{~km}$ the impact is estimated to have caused a $20-40 \mathrm{~m}$ tsunami on the South American/Antarctic coasts and was used as a possible explanation for some apparently unusual sediment distribution on East Antarctica. If the diameter was $4 \mathrm{~km}$, the tsunami may have been 10-25 times as great but would decay quickly. When discovered, it was the first record of a major impact in the world's oceans. As the chances of an asteroid of $10 \mathrm{~km}$ diameter hitting the Earth is only 1:10 years, it is likely that only one or two such craters exist on the modern seafloor.

Ocean Drilling Program Leg 189 (Exon et al. 2001) recorded 58 microtektites in a sample from Site 1169 on the west flank of the South Tasman Rise and Kelly \& ElkinsTanton (2004) suggested that they represent evidence of a late Miocene impact (site unknown and date not precise but likely to be about 5-10 Ma) and an event separate from any that deposited the well-known australites of Australia.

In March 2007, there was a report of space junk (experts suggested a meteorite) seen from a Lan Chile flight over the Southern Ocean.

\section{Other space sourced influences}

\section{Solar}

The regular 11-, or more strictly 22-, year sunspot cycle is well-recognised, but occasionally the sun produces extreme events.

In 1859, the British solar astronomer Richard Carrington witnessed what may have been the most extreme solar phenomenon over the past 500 years (Carrington 1859, Hodgson 1860, Tsurutani et al. 2003). Carrington had a private observatory devoted to the sun and projected a solar image onto a screen. At 11.18 am on 1 September 1859, he was surprised to see an enormous group of sunspots suddenly erupt into a white, kidney-shaped feature. The event lasted for about five minutes and by $11.23 \mathrm{am}$ had passed. It was thus large enough to be seen by the naked eye. It is now known as a white light solar flare and generated a flux of particles known as a Coronal Mass Ejection or CME.

The effects were several. The next day, the Earth was subject to red and green aurorae (including contemporary reports of purple), so strong that newspapers could be read before dawn and the auroras were even visible close to the tropics. Telegraph systems were severely disrupted and spark discharges from instruments set fire to telegraph paper.

On 6-19 March 1989, but especially on 13-14 March, was another such solar magnetic storm (Kurth 1991) and it was fortunate for humanity or planet Earth that it was directed largely away from Earth and directed away from one side of the sun. The event caused the power supply 
to six million Canadians to be turned off due to damage to production facilities. It is unclear how much damage was done to welds in major pipelines such as the TransAlaska pipeline because the event caused a major generator and, consequently, current-cancelling systems, to fail. The heating of the upper atmosphere induced by the CME led to increased atmospheric drag on spacecraft, and satellites dropped to lower orbits so that their orbits had to be re-calculated. GPS and such systems were inoperative for some 10 minutes. It has been estimated that such a flare could do some $\$ 30-\$ 70$ billion damage to space facilities if it occurred now.

It is completely unknown what damage was done to the Mir Space Station or its inhabitants. March 1989 was an active month for the sun with major activity on 13 March with lesser phases on 26-29 and 23 March. Effects were seen by the author from the Australian Antarctic supply ship MV Icebird south of Western Australia in broad daylight on 23 March 1989 and expressed as shimmering in the sky. Data for the period are available at: http://wdc.kugi. kyoto-u.ac.jp/index.html

There was another such event in 2001 and as instrumental observations have increased greatly in recent years, much more is known of this rather than of earlier events.

Two spikes in ${ }^{10} \mathrm{Be}$ occurred in ice cores from the Antarctic at 60000 and 35-40 000 years (Raisbeck et al. 1987). The origin is cosmic ray impact but what the event was that caused the development of ${ }^{10} \mathrm{Be}$ is unknown.

\section{Galactic/Extragalactic}

Supernovae produce an intense flash of gamma rays and ultraviolet light and that travels very rapidly as electromagnetic radiation. Particles travelling much more slowly arrive later, even hundreds of thousands of years later. The last supernova detected in our galaxy was noted in 1604.

Extragalactic events are rarer but are known as "bursters" and generate intense, long-lived gamma ray bursts. One possible source is hypernovae (a particular form of very large supernova) from the death of very large hydrogen/ helium stars. These occurred within the first billion or so years of the Big Bang at the beginning of the universe and are still detected. They are the oldest detectable events in the universe.

These events, collectively known as space weather, impact on the outer atmosphere causing chaos to communications systems, and in modern days, damage satellites, their inhabitants, and electronic facilities.

\section{EVENTS IN THE LONG TERM}

The following events can be classed as exogenous, one due to asteroid impact at a distant location, and the others as possibly global events with some sub-Antarctic contribution.

\section{Oceanic Anoxic Events (OAEs)}

During the Cretaceous, there were intervals of globally high temperature, enhanced Greenhouse conditions, and altered oceanic circulation patterns different from the modern thermohaline pattern. Three major, and several lesser, intervals are well-recognised. The major events are the Oceanic Anoxic Events (OAE 1-3) (Jenkyns 1980, Gertsch etal. 2010). Indian Ocean Cretaceous sediments reflect in part the influence of these events.
The marine environment was characterised by a stratified ocean which allowed the accumulation of organic-rich dark sediment and markedly reduced benthic activity. The organic-rich nature of the sediments has been invoked as a partial explanation for hydrocarbon generation.

\section{Terminal Cretaceous asteroid impact}

The seafloor and some island areas of the sub-Antarctic include rocks that are old enough to have experienced events that appear to be unique. Extinctions and climate change that were the defining events of the Cretaceous/Cenozoic transition were a result of a major asteroid impact on the Yucatan Peninsula in the Gulf of Mexico (Alvarez et al. 1980, Hildebrand et al. 1998). This event had global significance as the control on one of the major extinction events in global history, that at the end of the Cretaceous.

\section{Paleocene/Eocene Thermal Maximum (PETM) - possible gas hydrate release}

A major excursion in ${ }^{12} \mathrm{C}$, the lighter isotope of carbon, in marine plankton skeletons marks the Paleocene/Eocene transition (55 Ma) and appears unique in the time span (midCretaceous-Recent) for which records can be determined. It appears to have been caused by a massive release of methane (Dickens et al. 1997) into the atmosphere over a geologically short interval, sometimes quoted as being as short as 1000 years. It resulted in a geologically short-lived (recovery period of some 200000 years; Röhl et al. 2007) but sharp increase in global sea and atmosphere temperature by as much globally as $6^{\circ} \mathrm{C}$, higher in polar regions (Greenhouse conditions), in turn leading to significant extinction of marine benthos (Thomas \& Shackleton 1996). The cause of the release of methane is not fully determined but gas hydrates from below the seafloor are commonly quoted as a source and the North Sea has been suggested as the site of release.

\section{CONCLUSIONS}

The sub-Antarctic is subject to extreme events although the low population and observatory level makes their record less than perfect.

Endogenous events such as earthquakes, volcanic eruptions and their side effects (landslides, tsunami) can be monitored from elsewhere but are generated within the sub-Antarctic and their major impacts are felt there. Exogenous events from space are dominantly those affecting the entire world but also the sub-Antarctic, and are mainly solar or galactic in origin. Asteroid/meteor impacts are mainly from within the solar system.

With better understanding of the dynamics of planet Earth, endogenous events may become predictable but this is unlikely for most exogenous events.

\section{ACKNOWLEDGEMENTS}

Tim Barton at Geoscience Australia provided the detailed information on the 1998 earthquake. I thank Dr Marc Duldig for discussions about the possible space-related exogenous events. Noel Carmichael kindly provided the image of the Macquarie Island landslide and Larry Lackey sent me the image of the volcano Puyehue-Cordon. The sub-Antarctic 
realm is the subject of dedicated biennial conferences held in Hobart, Tasmania, since 2007 and the major distinguishing features have been identified. This paper was delivered to the Third sub-Antarctic Forum, 1-2 August 2011. I thank the organisers for the opportunity to express these ideas. I thank Drs M. Coffin and M. Duldig for constructive reviews.

\section{REFERENCES}

Alvarez, L.W., Alvarez, W., Asaro, F. \& Michel, H. 1980: Extraterrestrial cause for the Cretaceous/Tertiary extinction. Science 208, 1095-1108.

Carrington, R.C. 1859: Description of a singular appearance seen in the sun on September 1, 1859. Monthly Notices of the Royal Astronomical Society 20: 13-15.

Dickens, G.R., Castillo, M.M. \&Walker, J.C.G. 1997: A blast of gas in the latest Paleocene: simulating first-order effects of massive dissociation of oceanic methane hydrate. Geology 25(3): 259-262.

Exon, N.F., Kennett, J.P. \& Malone, M.J. (eds) 2001: The Tasmanian Gateway: Cenozoic climatic and oceanographic development. Proceedings of the Ocean Drilling Program, Initial Reports 189. Texas A\&M University, College Station TX: http://www.odp.tamu.edu/publications/189_ IR/189ir.htm.

Gass, I.G., Harris, P.G. \& Holdgate, M.W. 1963: Pumice eruption in the area of the South Sandwich Islands. Geological Magazine 100: 321-33.

Gersonde, R., Kyte, F.T., Bleil, U., Diekmann, B., Flores, J.A., Gohl, K., Grahl, G., Hagen, R., Kuhn, G., Sierro, F.J., Völker, D., Abelmann, A. \& Bostwick, J.A. 1997: Geological record and reconstruction of the late Pliocene impact of the Eltanin asteroid in the Southern Ocean. Nature 390: 357-363.

Gertsch, B., Adatte, T., Keller, G., Tantawy, A.A.A.M., Berner, Z., Mort, H.P. \& Fleitmann, D. 2010: Middle and late Cenomanian oceanic anoxic events in shallow and deeper shelf environments of western Morocco. Sedimentology 57: 1430-1462.

Green, G. 2007: Afterword. Papers and Proceedings of the Royal Society of Tasmania 141(1): 181.

Gubbins, D. 1999: The distinction between geomagnetic excursions and reversals. Geophysical Journal International 137(1): F1-F4.

Guillou, H., Singer, B.S., Laj, C., Kissel, C., Scaillet, S. \& Jicha, B.R. 2004: On the age of the Laschamp geomagnetic excursion. Earth and Planetary Science Letters 227: 331-343.

Heezen, B.C \& Ewing, M. 1952: Turbidity currents and submarine slumps and the 1929 Grand Banks earthquake. American Journal of Science 250: 849-873.
Hildebrand, A.R., Pilkington, M., Ortiz-Aleman, C., Chavez, R.E., Urrutia-Fucugauchi, J., Connors, M., GranielCastro, E., Camara-Zi, A., Halpenny, J.F. \& Niehaus, D. 1998: Mapping Chicxulub crater structure with gravity and seismic reflection data. In Grady, M.M., Hutchison, R., McCall, G.J.H. \& Rothery, D.A. (eds): Meteorites: Flux with Time and Impact Effects. The Geological Society, London: 155-176.

Hodgson, R. 1860: On a curious appearance seen on the sun. Monthly Notices of the Royal Astronomical Society 20: 15-16.

Jenkyns, H.C. 1980: Cretaceous anoxic events - from continents to oceans. Journal of the Geological Society 137: 171-188.

Kelly, D.C. \& Elkins-Tanton, T. 2004: Bottle-green tektites from the South Tasman Rise: deep-sea evidence for an impact event near the Miocene/Pliocene boundary. Meteoritics and Planetary Science 39: 1921-1929.

Kurth, W.S. 1991: The great solar storms of 1989. Nature 353: 705-706.

Leat, P.T., Larter, R.D. \& Millar, I.L. 2007: Silicic magmas of Protector Shoal, South Sandwich arc: indicators of generation of primitive continental crust in an island arc. Geological Magazine 144: 179-190.

Quilty, P.G. 1989: Landslides: extent and economic significance in Antarctica. In Brabb, E.E. \& Harrod, B.L. (eds): Landslides: Extent and Economic Significance in the World. A.A. Balkema, Rotterdam: 127-132.

Quilty, P.G. 2007: Origin and evolution of the sub-Antarctic Islands: the foundation. In Selkirk, P., Quilty, P.G. \& Davies, M. (eds) The sub-Antarctic. Papers and Proceedings of the Royal Society of Tasmania 141(1): 35-58.

Raisbeck, G.M., Yiou, F., Bourles, D., Lorius, C., Jouzel, J. \& Barkov, N.I. 1987: Evidence for two intervals of enhanced ${ }^{10} \mathrm{Be}$ deposition in Antarctic ice during the last glacial period. Nature 326: 273-277.

Röhl, U., Westerhold, T., Bralower, T.J. \& Zachos, J. C. 2007: On the duration of the Paleocene-Eocene thermal maximum (PETM). Geochemistry Geophysics Geosystems 8(12): Q12002, doi: 10.1029/2007GC001784.

Sutherland, F.L. \& Olsen, A.M. 1968: The persistence of drift pumice, from the 1962 South Sandwich Islands eruption, in southern Australasian waters. Papers and Proceedings of the Royal Society of Tasmania 102: 1-5.

Svensen, H., Planke, S., Malthe-Sørenssen, A., Jamtveit, B., Mykelbust, R., Eidem, T.R., \& Rey, S. 2004: Release of methane from a volcanic basin as a mechanism for initial Eocene global warming. Nature 429: 542-545.

Thomas, E. \& Shackleton, N.J. 1996: The Paleocene-Eocene benthic foraminiferal extinction and stable isotope anomalies. Geological Society London Special Publications 101(1): 401.

Tsurutani, B.T., Gonzalez, W.D., Lakhina, G.S. \& Alex, S. 2003: The extreme magnetic storm of 1-2 September 1859. Journal of Geophysical Research 108(A7), 1268 doi: 10.1029/2002JA009504

(accepted 6 November 2012) 